\title{
A Brief History of Race, Politics and Division in Trinidad and Guyana
}

Kahlia Brown

This essay will act as an analysis of the Indo-Afro racial politics of two west Indian countries: Trinidad and Tobago, and Guyana. I will give the circumstances that led to the migration of large numbers of East Indians as indentured servants to Trinidad and Guyana, specifically. I will also explain how these conditions led to a distinct form of government and society. Through tables of electoral data in Trinidad, the racial voting patterns will be observed, and I will elaborate on how political parties do or do not pander to their respective racial communities. Finally, I will conclude by addressing how the racial divide in these two large Caribbean nations impact Caribbean regionalism on a larger scale.

\section{Introduction}

There is a well-known history of the Caribbean that many will learn about through conventional schooling and the media. To provide some background, it is taught that in 1492, European colonizer Christopher Columbus sailed the ocean blue and discovered the "New World." The "New World," of course, was what is called the Americas today. It encompasses North and South America, as well as the Caribbean Islands scattered in between the two continents. In due time, European colonizers attempted to enslave the native populations of the Americas. This was done through the efforts of people like Bartolomé de Las Casas, who advocated for the peaceful conversion of indigenous populations, because they too were men with souls and their freedom, but who proposed African slaves as a means to compensate for lost labour forces (Anthony). In the Caribbean, native populations were depleted to nearly nothing by a number of ways, including but not limited to the diseases and war that Europeans brought with them (Huxley 57).

Soon enough, the Transatlantic slave trade was in full swing, with thousands of slave vessels controlled by the French, Spanish, English, Dutch, Portuguese, Danish and the US. It is estimated that, between 1519 and the mid $19^{\text {th }}$ century, approximately 11 million people were taken from Africa and enslaved. Varying accounts report that 9-10 million of those enslaved arrived to the Americas alive. Of those millions of people, around 4.7 million ended up in the Caribbean. This number is significantly larger than that of British North America, whose numbers totaled only 361,100 (Eltis 23). The Caribbean islands were unique in the sense that the enslaved population outnumbered the native or European populations, this remains true to this day, with some exceptions.

What followed is a history not as well known. Slavery was abolished in 1807, but this did not mean that slavery ceased to exist. On the contrary, the practice continued for decades after. During the time of emancipation, some plantation colonies had begun to dry up. The soil of Islands like Barbados, which was known for its high productivity, nor longer yielded as much as much as it once had. Planters began to look at islands that had not yet been overly exploited. One such island was Trinidad, which yielded 3-4 times as much product as its previously abundant predecessor, Barbados. Although slavery had been abolished, inter-colonial slave trade was just beginning. Planters migrated themselves and their enslaved Africans from the "Old Colonies," such as Barbados, Dominica and Jamaica, opting to settle in the then more fertile lands of 
Trinidad, Demerara (Now part of Guyana) and among others. There were laws against this but planters easily evaded them. Due to the ban on importing slaves, there were not enough labour forces in Trinidad and then Demerara. The abolition of slavery stood in the way of the success of planters. This consequently led to the search for new labour sources that would be used in the British West Indies.

May 30th is celebrated as a holiday in Trinidad and Tobago. May $5^{\text {th }}$ is a holiday in Guyana. These two dates share the same origin: Indian Arrival day. In 1838, the first vessel carrying Indian indentured servants arrived in Guyana, while in Trinidad this happened in 1845. There are parallels between the Transatlantic slave trade and the encouraged migration of Indian populations to the Caribbean: the exploitation of Africans and Indians were viewed as solutions to labour shortages. Africans were forced to carry out the labour that was previously done by now dwindling Indigenous populations. Following the abolition of slavery, the workforce was once again depleted, so indentured Indian servants were recruited to take up the work. From the $17^{\text {th }}$ to the $20^{\text {th }}$ century, India was a British colony.

The $19^{\text {th }}$ century was a particularly difficult one for some. Lower-class Northern Indians and displaced Bengalis found themselves in dire need of land and employment. Calcutta and Madras, both cities situated along the eastern coast of India, offered transport to British colonies. The Indians who migrated were referred to by the pejorative term Coolie. Coolie was a term that reflected their place in society. To be a coolie in the $19^{\text {th }}$ century was to be an unskilled labourer. Some definitions trace the term back to the Tamil word Kuli. According to Gaiutra Bahadur, the term was first used to refer to South Asians by Portuguese sailors looking for labourers. However, Indians were not welcome in all British colonies despite considering themselves British subjects. Indians were only welcomed where it benefitted the British. An example of this can be seen in the case of the passengers of the Komagata Maru in 1914, a ship filled with British passport holders and war veterans who also happened to be Sikh Indians. The shipped docked in Vancouver, but all those who were aboard were refused entry and sent back to India. Indians were allowed to migrate to other British colonies such as Fiji and Mauritius, but primarily to Trinidad and Guyana. According to Lomarsh Roopnarine, "... about 2.5 million nonEuropeans - mostly East Indian and Chinese - but also a substantial number of Africans, Javanese, Japanese and Pacific Islanders were brought to the Caribbean..." (2003). Of that number, 238,000 indentured servants were sent to Guyana and 143,939 to Trinidad.

There were conditions that came with labour migration: indentured servants were contractually obligated to work for their planter for up to 10 years, earning very little in wages. Edward Jenkins describes the ideal length of time for a term of indenturing: "I have been informed by the late Governor and by one of the principal planters of Trinidad that the one-year system works well, and, while encouraging independence in the Coolie, exercises also on the master a beneficial restraint, since he can only keep his best immigrants from year to year by kindly treatment" (1871). These were absolutely better terms of work than what the enslaved Africans received, but the planters or 'Masters' still retained control. The planters retained the right the punish their indentured servants for any infractions through imprisonment. Despite these clauses in their contracts, for many, being an indentured servant in the Caribbean was still better than being unemployed and landless in India. Indentured servants were rewarded for the contractual service with land and money. 
This is when hostilities worsened between the emancipated black population and indentured Indians. It is a trend we still see today: employers seek out cheaper labour, thus abandoning those who were previously employed. This breeds resentment. Rather than paying the former enslaved people fair wages, the planter sought to exploit a new group for human capital. Emancipated people now competed for employment due to the Indians being exploited for their labour and doing the jobs that former slaves were once forced to do for free, and for which they still have seen no reparations. This understandably led to tensions between the two ethnic groups and resulted in isolated communities. Indian communities existed mainly due to the social pattern of those who share common backgrounds gathering together. This can be observed in any place where mass immigration of certain groups occurs; we can look to Toronto's Little Italy for an example. But agglomerations like this are often also a group's response to the hostilities of others.

By this time coolie was used to remind those whose lives were shaped by colonizers of their exploitation. What made matters worse was that the white colonist did not want to encourage a relationship between its previous labour force its current one. Some Europeans in the Caribbean feared that the African population would encourage the Indians to incite riots. ${ }^{1}$ Daurius Figueira describes one European Reverend's views on the two races: "By Morton's testimony to Norman in January 1885 it is clearly apparent that Morton views the AfroTrinidadian as a disruptive element, a hindrance to the attempt to constitute the East-Indians as Gunga Din/Coolie." (2010, xxii). Europeans feared that the two groups would realize that they held power in numbers and hold back colonial attempts to domesticate their labourers. Note the reference to coolies: as previously stated, the word was used derogatorily against indentured servants the same way the n-word was used to label enslaved Africans. The words were and are still hurled between the Black and Indian communities in Trinidad and Guyana in order to belittle each other.

\footnotetext{
${ }^{1}$ Figueira, D. (2010). The politics of racist hegemony in Trinidad and Tobago. iUniverse.
} 


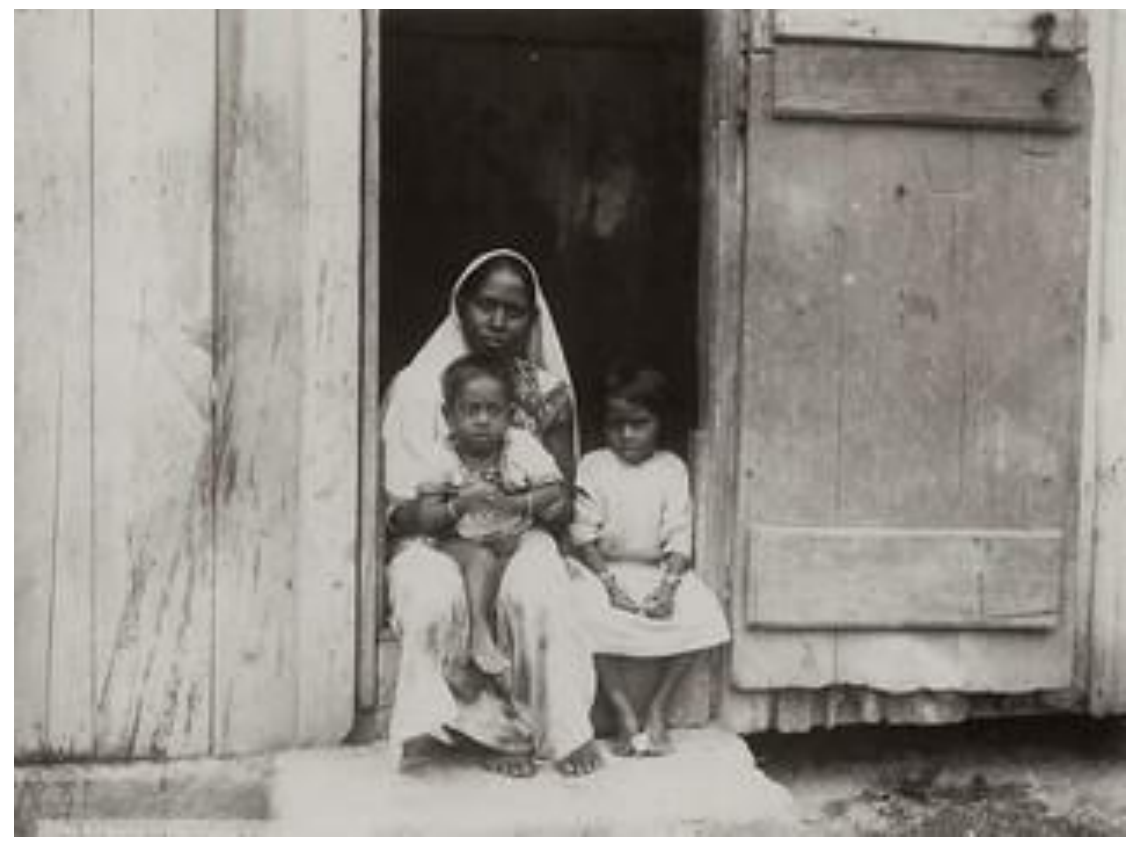

Figure 1. J. Murray Jordan - A Family In The Coolie Village, Trinidad, 1897

The system of indentureship that created the racial divide in Trinidad and Guyana would continue to the early $20^{\text {th }}$ century. However, when indentureship ended, Indians were in a far better position than their African counterparts had been when slavery was abolished. By the mid $20^{\text {th }}$ century, Indians were able to elevate their economic standing, now composing most of the 'urban' middle class. Indians were able to do so because of the aforementioned land and money to start businesses they received. Africans, who had been in the Caribbean for much longer, received nothing and rarely experienced any upward social mobility, remaining in the lower urban class.

In 1965, C.L.R James wrote West Indians of East Indian Descent. In it, he summarizes the prejudice and resentment that Indians and those he refers to as creoles, harboured towards one another. James quotes a man whose ethnicity he does not specify: “...An Indian got a job at the Base. Next thing every job in that department was held by an Indian. That is the way they are. They are all for each other, they think of Indians first" (1965). He goes on to further emphasize the division even in taxis. Indian drivers pick up Indian passengers and Indian passengers only enter Indian drivers' taxis (with some exceptions, such as if an Indian and African were personally acquainted). These behaviours seem to reveal an odd form of racial nepotism that likely emerged due to the group's instinct to congregate together and look out for one another. James, who was a very outspoken supporter of the Federation, encouraged nationalism instead, to consider the West Indians as a whole rather than East Indian-West Indians. He encouraged Indians to break the cycle of Indians and Africans being separated in politics. Though this thinking was absolutely necessary during this time, the populace was just not ready to hear it. James was always ahead of his time in his ideologies; he hoped for too much too soon. In the following decades, Trinidad and Guyana would prove that racial integration was nowhere in sight. 


\section{Guyana}

When Linden Forbes Sampson Burnham was elected as the first Prime Minister of Guyana in 1966, the racially-divided voting patterns of the Indians and Africans of the soon-to-be independent country were already evident. During this period, the Afro-Indo populations were finally able to speak for themselves, exhibiting self-rule. Prior to Caribbean independence, many liberal thinkers - including Dr. Eric Williams (Trinidad), Cheddi Jagan (Guyana) and Michael Manley (Jamaica) - advocated for Caribbean independence and unity in the form of federation. The federation was a Caribbean regional group that aimed to unite the Caribbean in order to benefit the region as a whole when competing in the global market, amongst other things. In a lecture given by Trinidadian Marxist C.L.R James in 1958, the rising racial tensions are briefly mentioned:

We heard that the East Indians in British Guiana were opposed to the Federation and these were the reasons given. They had a numerical majority over the other races, they hoped to establish an Indian domination of the colony; Federation would bring thousands of Africans (or people of African descent) from the smaller islands to British Guiana, these knew how to work land and how to build up from small beginnings. They would place the Indians in British Guiana in an inferior position. Therefore, the Indians were against Federation (1958).

James also noted that these sentiments existed in Trinidad as well. As previously stated, the Indians who were brought to the Caribbean (often of their own freewill) were able to work for wages; additionally, they were given land and money. The Indians dominated in numbers and land ownership, and most wanted things to remain that way.

Nevertheless, not all Indians believed that access to the same opportunities for Africans would mean a disadvantage for them. Cheddi Jagan, who was a co-founder of the PPP (People's Progressive Party) and the child of indentured servants, wanted to unite the Africans and Indians of Guyana. He saw the two groups for what they were, people who had been exploited and taken advantage of by the colonial system. Indeed, his seemingly non-biased racial views were something C.L.R James would praise him for.

Being a socialist, Jagan preferred to steer clear of racial politics; his ideologies were more in line with economic politics. However, Guyana itself did not reflect this. Jagan's supporters were largely Indian, and once the PPP became a party run mainly by Indians, the party's policies began to favour Indians. Despite Jagan's initial dreams of uniting the populace of Guyana under the shared experience of oppression, the opposite happened, and he perhaps unwittingly became the political face of the Indo-Guyanese people, even though his politics did not necessarily align with their own sentiments. Indians supported Jagan because he too was Indian, a fact he clearly understood (Marsal, 33). To this day, PPP's supporters are mainly comprised of Indo-Guyanese people.

On the other side of the Guyanese race politics was Afro-Guyanese lawyer Forbes Burnham. For years, Burnham also belonged to the PPP. However, he eventually broke with them formed his own political party, the People's National Congress, in 1957. I will not get into 
the specifics of party differences, but Burnham enjoyed foreign support because he was less radical than Jagan. Prior to the split, the PPP was a party that united the two races that made up the $80 \%$ majority in colonial Guyana. Burnham's choice to leave the PPP led to further racial divisions. Hintzen and Premdas write

With the split, there began a slow but inexorable ideological about-face by Burnham that was to culminate, later, in support for capitalist, prowestern policies. The opportunity for power for the Burnhamite faction was prescribed in ways that offered no other options. Burnham was supported by the more moderate East Indians in the PPP who had close ties with the East Indian professional and entrepreneurial urban middle classes. More importantly, he drew his mass support from the predominantly urban, black lower-class population. $(1983,179)$

Although there were some anomalies, much like Jagan, Burnham garnered most of his support from those who shared his lineage. The PPP and PNC represented very different ideologies and forms of government, but this was not necessarily a fact that Indians or Africans considered when voting.

\section{Trinidad}

In Trinidad, independence was achieved a few years before Guyana, but the political situations resembled one another. By the time the honourable first Prime Minister, Dr. Eric Williams (a man of mixed race: French creole and Black), was elected, the two-party. ethnically-divided system was in place. Williams was not, however, representative of the country's demographics as a whole, something that would work to his disadvantage in 1958. Colin Clarke states that in Trinidad, "The fact remains, however, that government and opposition in Trinidad, since adult suffrage was introduced in 1946, have been decided by racial blocks of majority (Creole) and minority (Indian) ..." $(1991,48)$.

Similarly to Guyana, pre-independence movements were largely composed of both ethnic groups who at the time shared a common goal. This momentary co-operation was not reflective of the racial politics in the country's history. Once the country's independence was attained, the two-party system was in place. Dr. Eric Williams, who is partially credited with spearheading the independence movement, was the head of the People's National Movement party founded in 1955. The main opposition party at the time was the Democratic Labour Party, which was a merger of three other parties ran by Bhadase Sagan Maraj (Indian) of the People's Democratic Party, Albert Gomes (Portuguese) of the Party of Political Progress Groups and Tubal Uriah Butler (Afro-Grenadian) of the Butler Party. The DLP was composed of three different racial groups, an optimistic start, but the party was led by Maraj. Until the party's split in 1971 (with the exception of Alloy Lequay, who saw the end of the party), the party was led by IndoTrinidadians and drew their support from the Indian middle class. When the PNM lost to the DLP in 1958, Williams attributed this to the Indian votes over which the DLP held the monopoly. The statistics prove that Williams was correct in his suspicions.

\section{TABLE 1 - Ethnicity and Voting in the 1958 Federal Election: Selected Polling Divisions}




\begin{tabular}{|l|c|c|}
\hline Division & $\begin{array}{c}\text { Number of } \\
\text { Indians }\end{array}$ & DLP Votes \\
\hline & & \\
\hline Tunapuna & 3,427 & 3,402 \\
\hline $\begin{array}{l}\text { Curepe and } \\
\text { St. Augustine }\end{array}$ & 3,140 & 4,284 \\
\hline Tacarigua & 948 & 911 \\
\hline Arouca & 1,567 & 1,454 \\
\hline D'Abadie & 313 & 272 \\
\hline Piarco & 277 & 300 \\
\hline Caroni & 1,272 & 1,313 \\
\hline TOTAL & 10,944 & 11,936 \\
\hline
\end{tabular}

TABLE 2 - Ethnicity and Voting in the 1958 Federal Election: Selected Polling Divisions

\begin{tabular}{|l|l|l|}
\hline Polling Division & Indians & DLP Votes \\
\hline & & \\
\hline 52 & 136 & 135 \\
\hline 53 & 20 & 21 \\
\hline 54 & 169 & 170 \\
\hline 55 & 235 & 228 \\
\hline 56 & 184 & 204 \\
\hline 57 & 245 & 249 \\
\hline 60 & 315 & 313 \\
\hline 63 & 56 & 52 \\
\hline 25 & 54 & 54 \\
\hline 26 & 51 & 54 \\
\hline 29 & 49 & 50 \\
\hline 34 & 106 & 103 \\
\hline 36 & 306 & 298 \\
\hline 39 & 117 & 116 \\
\hline 40 & 117 & 115 \\
\hline 17 & 206 & 205 \\
\hline 122 & 243 & 241 \\
\hline
\end{tabular}

TABLE 3 - Constituency and Ethnicity in Trinidad

\begin{tabular}{|l|c|c|}
\hline Constituency & African & Indian \\
\hline & $\%$ & $\%$ \\
\hline & & \\
\hline Couva North & 25 & 75 \\
\hline Couva South & 25 & 75 \\
\hline
\end{tabular}




\begin{tabular}{|l|l|l|}
\hline Tabaquite & 40 & 60 \\
\hline Naparima & 40 & 60 \\
\hline Siparia & 47 & 52 \\
\hline
\end{tabular}

These tables, taken from Selwyn Ryan's Social \& Occupational stratification in contemporary Trinidad and Tobago, prove a clear correlation between racial voting patterns. Indians almost exclusively voted for the DLP. However, the same could be said about Black voters. Ryan provides the example of Laventille, where Williams won $93.5 \%$ of the votes because the area was, and still is, made up predominately of Black people (Ryan 114). So while Williams complained of Indians voting blindly based on race, those who supported him did the same.

I would like to say that things in Trinidad got better in the following decades, but that would be untrue. In 1972, a political split occurred within the DLP, which gave the rise of the United Labour front came as the opposition. It came as no surprise that the party was led by an Indian: Basdeo Panday. In 1995, Panday would become Trinidad and Tobago's first Prime Minister of Indian descent. However, he was politically active for many years before that (Leung \& Deuber 12). Later, in 1988, he would go on to form the United National Congress.

Since then, the party has acted as the Indian opposition to the PNM. A more recent example of this can be found in the 1995 general elections in which the UNC defeated the PNM. By this time, the Indo-Trinidadian had surpassed the Afro-Trinidadian population, and tensions ran high. Neither party has openly state that it is pandering to its ethnic supporters, but both parties' recruitment practices say otherwise. In 1995, the PNM and UNC sought to maintain their ethnic support at the micro level:

It is at this level of intimate inter-personal communication that each of the two major parties made their communal pitch, invoking ethnic stereotypes, metaphors and prejudices so as to consolidate their support. In practically every case, the two major parties realized that the campaign canvasser, who was often a well known community leader such as a teacher, a church minister, a businessman, or a popular sport or musical personality, was of the same ethnic group as the local community he was active among." (Premdas and Ragoonath 39-40).

The parties organized community leaders in order to maintain or convert people. This was done essentially through fear mongering: Indians were scared with threat of African crime (Premdas \& Ragoonath 39), and the Africans were told to beware of an Indian take over (see James 1965). This is a pattern that has not since been broken: the two races have continued to vote for their respective party, and each party blames the other for the short comings of the country, with racial prejudice lurking in the background. The PNM, DLP, UNR, UNC, etc. have all acknowledged that their votes lie with their ethnicities; they rely on this fact, using it as a crutch to obtain power through bigotry.

\section{Concluding Observations}


The circumstances under which Africans were brought to the West Indies were atrocious. Indians being brought in as Indentured servants is not something that should be celebrated either; however, they were better off than the emancipated Africans. Indians migrated to the West Indies often to seek out better opportunities that they did not have in India, while enslaved Africans never had a choice. These circumstances ensured that Indians were more likely to succeed in the West Indies. After over a century in Trinidad and Guyana, Indians have used their privilege to make sure that their ethnic group prospered. By the mid- $20^{\text {th }}$ century, the Indian populations in both Trinidad and Guyana, were large enough to impact politics and form race-based parties.

Around this time in Guyana, it is clear that Indians did not support Federation. Indians, given their social and economic standing at the time, did not want unity; instead, they wanted prosperity for their community. Indians went out of their way to support other Indians within their respective country of residence but could not adopt the idea of united nationalism, because this would include the Africans. This inhibited not only national unification, but regional as well. If a country is divided by race and cannot be united internally, how can the it be expected to co-operate with neighbouring countries? The fact remains that Guyana and Trinidad and Tobago were and are countries divided along racial lines. During the independence and federation era, they were home to extreme racial unrest, and unprepared or unable to contribute to regional unity.

C.L.R James voiced his wishes for the racially divided countries of Trinidad and Tobago in his lecture on West Indians of East Indian Descent: "The people, of all races, want to put all this behind them and begin a new life. That is why we want and must have the new party" (1965). He believed that the people of the West Indies wanted to move past governments that were divided by race, and he encouraged the formation of a new party that would represent all demographics. This is a feat that some have attempted to achieve; thus far, however, very little progress has been made moving away from the Indo-Afro two-party dominant systems of Trinidad and Tobago and Guyana. 


\section{Works Cited}

Anthony, D. (2015, July). July 2015: Bartolomé de las Casas and 500 Years of Racial Injustice: Origins: Current Events in Historical Perspective. Retrieved from http://origins.osu.edu/milestones/july-2015-bartolom-de-las-casas-and-500-years-racialinjustice.

Bahadur, G. (2013). Coolie woman: The odyssey of indenture. University of Chicago Press.

Clarke, C. (1991). Society and electoral politics in Trinidad and Tobago. In Society and Politics in the Caribbean (pp. 47-77). Palgrave Macmillan, London.

Eltis, D. (1972). The Traffic in Slaves between the British West Indian Colonies, 18071833. The Economic History Review, 25(1), new series, 55-64. doi:10.2307/2599736

Eltis, D. (2001). The Volume and Structure of the Transatlantic Slave Trade: A Reassessment. The William and Mary Quarterly,58(1), 17-46. doi:10.2307/2674417

Figueira, D. (2010). The politics of racist hegemony in Trinidad and Tobago. iUniverse.

Grace, S., \& Helms, G. (1998). Documenting Racism: Sharon Pollock's The Komagata Maru Incident. Painting the maple, 85-99.

Hintzen, P. C., \& Premdas, R. R. (1983). Race, ideology, and power in Guyana. Journal of Commonwealth \& Comparative Politics, 21(2), 175-194.

Huxley, G. L. (1980). Aristotle, Las Casas and the American Indians. Proceedings of the Royal Irish Academy. Section C: Archaeology, Celtic Studies, History, Linguistics, Literature, 57-68.

James, C. L. R. "Lecture on Federation (West Indies and British Guiana)." Demerara: The Argosy Company (1958).

James, C. L. R. (1965). West Indians of East Indian Descent. Retrieved from https://www.marxists.org/archive/james-clr/works/1965/eastindians.htm.

Jenkins, E. (1871). The Coolie, His Rights and Wrongs: Notes of a Journey to British Guiana, with a Review of the System and of the Recent Commission of Inquiry (No. 7432). Strahan \& Company.

La Guerre, J., \& Girvan, C. (1972). THE GENERAL ELECTIONS OF 1946 IN TRINIDAD AND TOBAGO. Social and Economic Studies, 21(2), 184-204. Retrieved from www.jstor.org/stable/27856528 
Leung, G. A., \& Deuber, D. (2014). Indo-Trinidadian speech. English in the Indian Diaspora. Amsterdam: Benjamins, 9-27.

Mars, P., \& Young, A. H. (Eds.). (2004). Caribbean labor and politics: legacies of Cheddi Jagan and Michael Manley. Wayne State University Press.

Meighoo, K. (2002). Basdeo Panday: A Political Biography.

Premdas, R. R., \& Ragoonath, B. (1998). Ethnicity, elections and democracy in Trinidad and Tobago: Analysing the 1995 and 1996 elections. Journal of Commonwealth \& Comparative Politics, 36(3), 39.

Reddock, R. (2008). Indian Women and Indentureship in Trinidad and Tobago 18451917: Freedom Denied. Caribbean Quarterly, 54(4), 41-68. Retrieved from www.jstor.org/stable/40654698

Roopnarine, L. (2003). East Indian Indentured Emigration to the Caribbean: Beyond the Push and Pull Model. Caribbean Studies,31(2), 97-134. Retrieved from www.jstor.org/stable/25613409

Ryan, S. D. (1991). Social and occupational stratification in contemporary Trinidad and Tobago. Institute of Social and Economic Research, University of the West Indies. 113118

Tables and Figures:

Figure 1.

1. Jordan, J. M. (2008). A Family In The Coolie Village, Trinidad, 1897. photograph, St. James Town . Retrieved from https://www.flickr.com/photos/caribbeanphotoarchive/3099091860/in/album$72157608769702677 /$

Tables 1, 2, 3 and 4.

2. Ryan, S. D. (1991). Social and occupational stratification in contemporary Trinidad and Tobago. Institute of Social and Economic Research, University of the West Indies. 113118 